\title{
EDUCATING FOR ISLAMIC PLURALISM: LESSONS FROM INDONESIA
}

\author{
Asna Husin*
}

\begin{abstract}
Islam views diversity in the human family to be the inherent divine order in creation (sunnat Alläh) for such differences aim at promoting mutual understanding (ta āruf) and partnership between distinctive human individuals and groups. The divine purpose in creating plurality is to allow religious communities to 'strive with one another as in a competition' in establishing benevolence and goodness in this world. The author looks at how Indonesian schools teach pluralism to youth through religious and non-religious courses. The model is exclusive loyalty to Islam with an underlying Islamic tolerance and respect for other faiths. She also surveys how an Islamic view of plurality is being taught in post-Suharto Indonesia through both conventional approaches to instructing religion and non-religious based initiatives of civic education. Her discussion ends with the practical teaching of plurality through 'aqĩdah/akhlāq-peace education in Aceh, highlighting a viable new synthesis in teaching religion through creatively presenting the qur'ānic worldview of plurality reflecting Islam's high-minded generosity toward other faiths. As she argues, teaching Islam in our global age should be accomplished in as attractive a manner as possible to young Muslim minds and hearts, without compromising the sacred nature of religion and its special position in human consciousness, aspirations and activities.
\end{abstract}

\section{Introduction}

Islam views diversity and pluralism in the human family - be it physical such as skin colour, or cultural in the form of behaviour and worldview, or spiritual as manifested in religious doctrines and practices - to be the inherent divine directive of creation. The Qur'ān often speaks of this reality by inviting Muslims not only to accept human differences but above all to embrace and celebrate this diversity as a matter of divinely prescribed principle. Furthermore, Islamic teachings clearly enunciate the purpose of this divinely intended human plurality to be the enhancing of human

* Dr Asna Husin is the Director of the Peace Education Programme (Program Pendidikan Damai, PPD, an NGO) and a Lecturer at the State Institute for Islamic Studies (IAIN Ar-Raniry) in Darussalam, Banda Aceh, Indonesia. 
progress and wellbeing. Regarding physical and cultural diversity, the Qur'ān proclaims (49:13) that such differences aim at promoting mutual understanding ( $t a \bar{a} r u f$ ) and partnership between distinctive human individuals and groupings, with the higher spiritual objective of reaching divine consciousness (taqwā) transcending the physical and cultural plane, this being the most honoured achievement of a man or a woman in God's sight. On doctrinal and religious diversity the Qur'ān stipulates $(5: 48)$ that the divine purpose is to test religious communities on how they live up to the principles of their particular religious laws and ethical codes by 'striving with one another as in a competition' to see whom among them are the best in establishing benevolence and goodness (istabiqū 'l-khayrāt). ${ }^{1}$ These teachings of the Qur'ān about pluralism gave birth to the historically attested Muslim appreciation of cultural diversity and religious complexity, and today more than ever in the past needs to be implanted in the minds of Muslim youth through both formal and non-formal education.

Disseminating Islamic norms of diversity in today's world varies from one Muslim community to the next and from one Islamic nation to another. Here we will look at the ways Indonesia as a national community transplants Islam's pluralistic seeds promoting shared living and co-existence between religions. Indonesia is selected for several reasons. It is the largest Islamic country in the world with a total Muslim population of over 210 million ( 87 per cent of its population), and officially recognises the multiplicity of religions, ethnicities and cultures. Despite recent religious tensions in some areas within its borders, this archipelagic nation of over 17,000 islands largely remains a nation of diverse communities living side-byside in harmony. Finally, as a major country gaining more confidence in its Islamic identity and post-Suharto mode of democracy and decentralisation, ${ }^{2}$ Indonesia has become more open and relaxed allowing many new initiatives to be tested in its school system. As socio-political decentralisation has taken root across the country, new educational projects follow its course. Some schemes are nationally oriented,

1. Qur'ān 5:48: “To every one of you We have appointed a Right Way and a Manifest Path of Conduct. If God so willed He would have made you all one religious community - but [He divided you into differing groups] so that He may test you by that which He has given you. Therefore compete with one another in performing good works! Unto God shall you all return, then shall He inform you of that whereon you were at variance." Consult two excellent articles, one by a Muslim and the other a Christian: Mahmoud Ayoub, "The Qur'an and Religious Pluralism", in: R. Boase (ed.), Islam and Global Dialogue. Religious Pluralism and the Pursuit of Peace (Aldershot: Ashgate, 2005), 273-381, and Isa J. Boullata, “Fa-stabiqu 'l-khayrat: A Qur'anic Principle of Interfaith Relations", in: Yvonne Y. Haddad and Wadi Z. Haddad (eds), Christian-Muslim Encounters (Gainesville, FL: University Press of Florida, 1995), 43-53.

2. Suharto, the second President of Indonesia who ruled the country with an authoritarian hand for over 30 years, was removed by public protests in the aftermath of the 1997/98 Asian economic crisis, putting an end to his military regime and giving birth to democracy, making Indonesia now the largest Muslim majority democracy in the world. 
while many others are promoted by local governments and groups for specific areas within Indonesia's borders.

Educating young minds and hearts in Islamic principles of pluralism also shares these two approaches: national and local. We wish to explore the dynamics of these central and provincial-district orientations when teaching Islamic pluralism to young Muslims. We start by reviewing the history of teaching Islamic pluralism throughout the modern Indonesian state focusing on the teaching of religion (Indon.: agama) from primary school to high school covering twelve years of education. Secondly, we survey national schemes of teaching pluralism in postSuharto Indonesia, reviewing both the conventional approach of teaching agama and non-religious based initiatives including civic education and human rights education. Finally we examine a more specifically Islamic-based endeavour in teaching ideas of diversity as practised currently in the westernmost province of Aceh through peace education initiated by the local nongovernmental organisation Program Pendidikan Damai (PPD or 'Peace Education Program'). This initiative is supported by the government of Aceh and its leading Ulama umbrella organisation the Ulama Council of Acheh. Our survey concludes with reflections on how to synthesise Islam's teaching on pluralism for presentation to Muslim youth living in a twenty-first-century global environment. ${ }^{3}$

\section{Cultivating Islamic Plurality}

Post-colonial Indonesia has always presented itself as a multi-religious multi-ethnic state that neither recognises a specific 'state religion' nor denies religion a role in nation-building by formally adopting secular values separating religion and politics. ${ }^{4}$

3. This study draws on personal experience and knowledge of educational practice in Indonesia, as well as research into the field of philosophy of education. For the benefit of those wishing to learn more about this topic, the following publications in Indonesian provide orientation and guidance: M. Nashir Ali, Lintasan Sejarah Pendidikan di Indonesia (Jakarta: IKIP Muhammadiyah Jakarta Press, 1994); Departemen Pendidikan dan Kebudayaa, Pendidikan di Indonesia dari Jaman ke Jaman (Jakarta: Balai Pustaka, 2nd ed., 1986); Hasbullah, Sejarah Pendidikan Islam di Indonesia (Jakarta: Rajawali Press, 1995); F. Jalal and D. Supriadi (eds), Reformasi Pendidikan dalam Konteks Otonomi Daerah (Yogyakarta: Adicita, 2001); Nurkholis, Manajemen Berbasis Sekolah: Teori, Model dan Aplikasi (Jakarta: PT Gramedia Widiasarana Indonesia, 2003); B. Suryosubroto, Manajemen Pendidikan di Sekolah (Jakarta: PT Rineka Cipta, 2004); and Zainur Roziqin, Moral Pendidikan di Era Global (Malang: Averroes Press, 2007).

4. The fact that Indonesians comprise multi-ethnic and multi-cultural communities of over 350 linguistic and cultural groups helps them in understanding the complexity of religious differences. Even in a place such as Aceh with only 4.2 million people, there are at least eight Acehnese subethnic communities with differing languages and cultures yet united by Islamic identity and their unique Acehnese sense of history. These are in addition to a half-dozen other Indonesian communities that call Aceh home. So it is quite natural that appreciation for living in multi-ethnic and multi-linguistic communities is translated into tolerant respect for religious co-existence as the preferred norm. 
The acknowledgement of the religious contribution to enriching the country is manifested in the state promotion of religion, especially Islam as the religion of the overwhelming majority. Within this government policy falls the mandatory teaching of religion (pelajaran agama) to all children enrolled in schools. ${ }^{5}$ From its inception as a modern state Indonesia has followed a dual educational system of a general public school (sekolah umum) and a religious school (sekolah agama - i.e. Islamic madrasah). Both types, running from pre-school up to university level, ${ }^{6}$ are government institutions supported by public funds and are administered by two separate Ministries: the madrasah system under the Ministry of Religious Affairs and the sekolah under the Ministry of National Education.7 The madrasah teaches many religious courses providing students with ample opportunities to study pluralism through the subjects of 'aqīdah and tawhīd (Islamic creed and doctrine), the Qur'ān and tafsīr (Scripture and exegesis), as well as Islamic history and civilisation. From their non-religious subjects, students learn about diversity and co-existence through national and world history, sociology and several other courses, since Indonesian schools, like many schools in other Muslim societies, teach social sciences within the context of the prevailing Euro-American worldview, overlooking centuries of Muslim civilisational contributions to the development of knowledge and the humanities. In spite of this strong Western orientation in teaching non-religious subjects, the issue of religious pluralism penetrates the minds of students through the framework of the qur'ānic notion "lakum dīnukum wali $a l-d \bar{\imath} n$ / for you your religion and for me mine" (109:6) emphasising an absolutist sense of Islam's exclusive truth. ${ }^{8}$

5. As the nation widens its pre-school education (pendidikan usia dini) over the last two decades, coupled with citizens' strengthening their Islamic identity, the pelajaran agama, though not mandatory, has become an ingredient of pre-school curricula and is being taught to children as young as three years of age.

6. A number of State Institutes for Islamic Studies (IAIN) existing across Indonesia are higher educational institutions under the jurisdiction of the Ministry of Religious Affairs (Departemen Agama), as opposed to regular state universities such as the University of Indonesia in Jakarta or Syiah Kuala University in Banda Aceh which are managed by the Ministry of National Education (Departemen Pendidikan Nasional). Several of the IAINs have recently been transformed into fullfledged State Islamic Universities (UIN).

7. The curricula of these two types of schools have evolved over the years with the current existing standard of the madrasah dividing its subjects into a ratio of 30 per cent Islamic components, including Qur'ān and tafsīr, 'aqīdah and akhlāq, fiqh and ușūl al-fiqh, tawhīd and kalām etc., and 70 per cent non-religious courses such as biology, geography, linguistics, mathematics, physics, etc. The sekolah, on the other hand, teaches all non-religious subjects with the exception of a minimum two-hours course or about 80 minutes - pelajaran agama (religion course).

8. The way Muslims view 'the Other' changes as students enter university. In most cases they become more open to dissenting views. The political atmosphere also influences students' attitude toward the 'Other'. In the second decade of Suharto's rule (c. 1975-90) the Government regarded Islam as an enemy of the state perceiving that Muslim leaders were trying to replace the nation with an Islamic system, while Muslims were generally of the opinion that Christian leaders in the military 
In contrast, the students in the public sekolah have limited opportunities to study Islam's view of pluralism through Islamic subjects, for in most cases they study agama for only 80 minutes weekly focusing largely on the principles of faith and practice, worship, and history. ${ }^{9}$ Yet like their fellow madrasah students they possess many occasions to learn about pluralism through non-religious subjects. Muslim sekolah students, especially those who live in multi-cultural and multireligious communities, engage daily with their non-Muslim classmates giving them an opportunity to understand others at a more personal level. Since Indonesia recognises five religions ${ }^{10}$ and requires public schools to teach pelajaran agama to students by a teacher of the same faith as themselves, all public schools have to hire religion teachers conforming to the religion(s) of their pupils: ${ }^{11}$ Islam has to be taught by a Muslim teacher, as Christianity is instructed by a Christian teacher and so on, provided that a school has a minimum of five students of a specific religious group. This opportunity to clearly identify oneself as Muslim once weekly in their Islamic religious course, while classmates adhering to other religions participate in their own separate agama classes, affords a genuine experience allowing students to reflect on religious differences. Despite such opportunities for students in the

contributed to Suharto's dislike of Islam. In that political climate it was difficult for Muslim students to embrace the non-Muslim 'Other', especially those in the madrasahs who had limited opportunities to be engaged with non-Muslims in day-to-day class activities. It appears that Islam's teaching of respecting 'the Other' became one of the restraints preventing these Muslim youths from getting involved in such politico-religious conflict. For the dynamic of Muslim-Christian relations during the Suharto era, consult Mujiburrahman, Feeling Threatened: Muslim-Christian Relations in Indonesia's New Order (Amsterdam: Amsterdam University Press, 2006).

9. Sekolah students' opportunities to study Islam have progressed in the last 20 years as Indonesian communities moved toward deeper Islamic identity. In addition to enrolling in sekolah, many children also join afternoon religious courses at private diniyya schools (lit. 'religious', short for madrasah dīniyyah) run by a community or mosque and found everywhere. Subjects studied at these are as complex as those of the state school and public madrasah, but due to the young age of pupils the focus of teaching in the diniyya is on basic principles and practice of Islam with little or no emphasis on religious pluralism.

10. These are Islam, Christianity (both Catholic and Protestant), Hinduism, Buddhism and Confucianism. This last was finally included as a religion of the nation shortly after the fall of Suharto in the aftermath of the 1997/98 Asian economic crisis.

11. Indonesia's new education law passed in 2003 also required private schools, including those run by Christian or Muslim organisations, to teach agama to their students by a teacher of the same religion. This means that Christian schools have to teach Islam to their Muslim students and this is taught by a Muslim teacher hired for the purpose. The same is true for other private religious schools. This specific stipulation generated heated debate over a long hearing in Parliament while various groups took to the street to protest for or against this provision. As can be easily discerned, the Muslim groups, along with Hindus and Buddhists that have always seen Christian schools as a form of active proselytisation, supported this ruling, while Christian organisations were against it. The bill was finally passed by majority vote but without a single ballot from Megawati's Indonesian Democratic Party of Struggle (Partai Demokrasi Indonesia Perjuangan), for all of its party members walked out of parliament to protest this stipulation. This event underlines the complex dynamics of embracing pluralism in Indonesia's socio-political context. 
sekolah system to know one another on an interpersonal basis, most of these Muslim students do share the perception of their madrasah counterparts about the 'Other' with its underlying absolutist conception that Islam alone possesses exclusive truth and is superior to other religions.

Such an exclusivist truth-claim may be seen by some as dangerous for it can lead to condemnation of non-Muslim others or even contribute to violent conflicts. However, many thinkers argue cogently for the view that such exclusivist religious conviction and absolute loyalty to one's faith is common among most religious communities, and is vitally important for the health of our communal human life. ${ }^{12}$ Several reasons may be given to support this trust:

1. The negative view regarding absolutist universal religious expression as a major factor triggering damaging conflicts is, according to the Archbishop of Canterbury Dr Rowan Williams, a "hopeful fantasy" of those who happen to be in power, for it implies that power is more important than truth. While in reality to be assertive about the validity of truth is "to recognize that there are things about humanity and the world that cannot be destroyed [...] or dismantle[d]" by power, for such power, even when seemingly working for the good of the majority, cannot guarantee that certain values and visions shall remain operative for whatever reasons. ${ }^{13}$ In Archbishop Williams's understanding, disagreement over religious truth "does not" provoke the violent disruption of social harmony, but on the contrary "a robust view of disagreement and debate between religious communities may (unexpectedly) play a major role in securing...social unity and cohesion". The Archbishop states that belief in the absolute truth of one's religion is to hold that the object of one's belief is not vulnerable to contingencies of human history, with the implication that God's nature and irādah (will) cannot be changed by what happens in this world. Thus a defeat or apparent failure in this world of one's faith, is not a failure or defeat of God. ${ }^{14}$ Nevertheless, with such a conviction religious people cannot justify violent contest, for the divine does not need protection by human violence. The truth of the matter is that a fundamental lack of insight and understanding is what leads to religious violence due to the insecurity and shallow comprehension of a religion's adherents. ${ }^{15}$

12. See e.g., Mohammad A. Shomali, Ethical Relativism: An Analysis of the Foundations of Morality (London: Islamic College for Advanced Studies Press, 2001), 114-27 on 'Ethical absolutism and diversity of morals', reviewing a variety of contemporary thinkers upholding this view against relativistic pluralism.

13. Dr Rowan Williams, "Religious Diversity and Social Unity", public lecture delivered in Singapore on 6 December 2007, at an event jointly hosted by the Anglican Diocese of Singapore and the Islamic Religious Council of Singapore (MUIS).

14. Ibid.

15. Ibid. 
2. Absolute loyalty to one's faith also means that a person take into consideration all its essential teachings, including the seemingly contested ones, and weigh them according to one's experience, knowledge and wisdom. Absolute attachment to the divine, coupled with wisdom and understanding, will lead thinking religious individuals to apprehend God in His loving-kindness ( $\mathrm{rahmah}$ ), and thus no act of exclusion or violence can be associated with such divinity. They may be guided to understand that the reason for religious diversity and plurality of faiths springs from a divinely intended purpose, without thereby detracting from or minimising their commitment to the superiority of their particular religion. The qur'ānic teaching affirming religious plurality while confirming the universality of Islam offers an advanced model which humanity has yet to digest. ${ }^{16}$ This higher spiritual understanding of the complexity and variety of human religious convictions may be understood in a much simpler way as comprehended by pious religious commoners and literalist religious practitioners.

One's absolute truth-claim informed by adequate practice and knowledge as well as common sense, does direct individuals (including Muslim students in Indonesia) to behave in a manner that is religiously and socially sound, since religious faith is not something emerging in a vacuum. This is the most likely explanation why most Muslims, like many sincere believers of other faiths, are peaceful compassionate neighbours in spite of their conviction that Islam possesses absolute universal truth. Indeed, lived religious experience is a complex matter, and absolute attachment to God and the practice of one's faith does not necessarily lead one to intolerance of or violence toward the 'Other' - on the contrary this may enable the person to become a sincerely selfless individual who respects the inherent dignity of the 'Other'.

3. The Absolute truth-claim is spiritually and psychologically essential for most adherents of the revealed universal religions. It gives people of faith a strong sense of direction and purpose in life preventing them from falling into scepticism and doubt. To live religious faith is not the same as expressing mundane opinions and conditional loyalties that can be altered for particular worldly reasons and social, economic or political impulses. Rather, it is something permeating one's whole organism and being, physically manifested in one's words, thinking, emotions and behaviour. This may well be the chief reason that voluntary conversion among the learned of the knowledge-based religions is rare compared to that among members of simpler uneducated communities. However, this does not deny the fact that the well-educated knowledge-possessors do convert

16. For a summary analysis of the absolute particularities of religions within the universality of Islam, see Reza Shah-Kazemi, "Beyond Polemics and Pluralism: The Universal Message of the Qur'ān", paper read at The Cairo Conference on Azhar and the West-Bridges of Dialogue, 5 January 2009. 
voluntarily, but rather conveys that conversion by choice only occurs when the individual loses their confident sense of religious purpose and meaning, due to the reality that they no longer assent sincerely to the absolute truth of their existing faith. The relevant lesson to be drawn is that psychological confusion and lack of certitude about one's religious faith is one of the main risks inherent in relativistic truth-claims. Therefore Muslim youth in Indonesia, like many young adults around the world, should be supported in their absolute loyalty to Islam.

\section{New Efforts in Teaching Pluralism}

As Indonesia becomes more democratic after the Reformasi, decentralisation of government took shape, giving birth to new dynamics within the state apparatus allowing provincial and district political entities to have more say in directing local social and economic affairs. Issues that were taboo during Suharto's reign began to be debated openly, offering more opportunities for both local governments and community organisations to play direct roles in the development of their society. Local and regional nongovernmental organisations (NGOs) mushroomed across Indonesia becoming more active while gaining global profiles as they began working in partnership with various international donors. Furthermore, this transformation facilitates local governments designing their own programmes and projects, providing ample opportunity for 'peripheral' creativity. International bodies which used to work only with the national government, began to develop new initiatives and schemes in cooperation with local political and community entities. While this new openness and instant democratic change brings its own special challenges, these fall outside the purview of this study.

In the context of education, the conventional national programmes continue but are being strengthened with local inputs, as school teachers across the country are told that they can develop their own teaching plan and select its materials by using the national curriculum as a general guideline. Local governments are forced to become more creative and accountable as education stakeholders demand better services. International donors, such as the United Nations Children's Fund (UNICEF) and the Canadian International Development Agency (CIDA), in partnership with provincial and district governments as well as local NGOs, assist in strengthening education governance and designing programmes. New educational initiatives and progressive ideas, including participative and active learning as well as human rights education, are being introduced both at the national level and as local schemes. In the context of teaching Islamic pluralism, human rights education is becoming an important medium initiated at both national and local levels. 
Before we explore this new approach to instructing religious diversity, we will revisit existing conventional methods of teaching diversity through pelajaran agama and non-religious subjects touched upon above. The overall materials of non-religious courses relevant to diversity taught at both madrasah and sekolah in post-Suharto Indonesia have changed little, but the emphasis may have developed. For example, in the course on 'Western History' the focus in Indonesia's predemocratic period was on Europe as the nation dwelt on the brutality of colonialism and its impact on contemporary Indonesia, and as the Cold War between the Soviet Union and the Western bloc affected the country's existence and sense of direction. When the United States emerged as the sole superpower and its cultural and financial grip over the world including Indonesia strengthened, transforming it into a "neo-colonial" presence in the view of many citizens of the global south, the emphasis of Indonesia's 'Western History' course now focuses upon America. Globalisation and access to information technology in Indonesia's urban centres also shapes ideas about pluralism which young Indonesian Muslims receive, but this information is a product of outside schooling. As far as formal education is concerned, both the madrasah and sekolah continue to focus on providing sound and constructive education, while often they must compete with electronic media in shaping the minds of Muslim youths. This highlights the continuing importance of non-religious subjects for teaching religious diversity to Muslim students in post-Suharto Indonesia.

Although course materials for non-religious subjects related to teaching pluralism remain constant, the methodological approaches utilised for their instruction are gradually being transformed to meet the demands of teaching by means of active learning. ${ }^{17}$ This new methodological orientation sometimes is practised effectively, but frequently remains understood only at the level of discourse or theory not applied in practice. This gap reflects a critical aspect of educational challenges in Indonesia, highlighting that efforts at creating schools which are children-friendly and at making the teaching-learning process a joyful undertaking for both teachers and students is an unfinished initiative still evolving. ${ }^{18}$ In the context of the endeavour

17. As both the madrasah and sekolah systems were decentralised, the mode of teaching through 'active, joyful and effective learning' (AJEL), or its Indonesian equivalent PAKEM (Pembelajaran Aktif, Kreatif, Efektif dan Menyenangkan), is receiving more serious attention. Democratic reforms and decentralisation of education have encouraged local governments to be more responsive to local needs, and school teachers to be more active and creative in their teaching activity. The involvement of international agencies and local NGOs in improving the capacity of teachers is also an important ingredient of this new approach. Consult the brief description of creative learning, PAKEM (Pembelajaran Aktif, Kreatif, Efektif dan Menyenangkan) (Jakarta: UNESCO-UNICEF-Departemen Pendidikan, 2003); also available online at http://www.unicef. org/indonesia/id/MBS_13-37.pdf (accessed on 5 February 2009).

18. Unfortunately, no survey has been conducted to document the number of schools or teachers who are using or not using AJEL nationally for their teaching method. 
to enhance understanding of diversity, this suggests that those teachers who have been teaching through active learning are helping to empower their students far better than teachers using the old methodology of lecturing (ceramah),${ }^{19}$ since the former focus on all three dimensions of children's empowerment: knowledge about Islamic principles of diversity, skills on how to live together or manage conflicts when they emerge due to differences, and displaying proper attitudes toward others different from oneself.

To show the richness of this new methodological orientation for teaching plurality, we shall explore briefly the teaching of civic education (pendidikan kewarganegaraan or PKn, lit. 'citizenship education'). PKn has been taught in one way or another in schools across Indonesia under various names. ${ }^{20}$ The subject became mandatory in all schools at all levels only in 1989 when the country adopted a new education law. ${ }^{21}$ The teaching of PKn during the Suharto era was to indoctrinate students to subscribe to the unitarian nation-state as envisioned by his regime, and also to strengthen his authoritarian rule, utilising the ceramah methodology. In post-Suharto Indonesia this same subject is being taught but with fresh democratic stimulations inspiring students to become good citizens through appreciation of creative thinking, clean and responsible governance, and direct involvement in the democratic process. The conventional issues of the character of citizens for the nation, the importance of people's innovation and creativity, and keeping Indonesia united and strong, continue to be taught. But the ideas of Indonesia as a pluralist society, respect for human rights and civic institutions, as well as the importance of Indonesia's involvement in the global arena become emphasised in contemporary teaching of

19. Until quite recently the ceramah approach was widely utilised by all teachers across the country in the instruction of all subjects. Though it has its merits, the method has been criticised fiercely for its one-way street fashion, fostering a classroom where only teachers are active while students are treated as objects in the learning process. Among other weaknesses of this approach is that the ceramah concentrates greatly on strengthening students' cognitive aspects while overlooking the affective and aptitude dimensions in their growth process. Without discarding the ceramah, the new active learning approach is being introduced to instigate all three qualities within pupil development.

20. One name was Pendidikan Moral Pancasila (Pancasila Moral Education, or PMP). Pancasila refers to the Five Principles introduced at the foundation of Indonesian nationhood: belief in One God, humanity, national unity, democracy, and social justice, and is best known as the 'philosophy of the nation' (falsafah negara).

21. The requirement to teach the Pancasila moral principles to students was not a surprise to Indonesians and observers of Indonesian politics, for early in the 1980s Suharto had enforced by means of "political terror" the "sole foundation' policy (asas tunggal) requiring all organisations, including religious ones, to make the Pancasila to be their sole foundation, while adult citizens, especially public servants, were obliged to take a week-long, or even two-week, course reflecting upon and implementing the Pancasila values. On the dynamics of the asas tunggal policy and its unintended positive impact on Muslim socio-political activities in Indonesia, see Robert W. Hefner, Civil Islam: Muslims and Democratization in Indonesia (Princeton, NJ: Princeton University Press, 2000), 121-3. 
PKn. All these alterations reflect the needs of the new era of Indonesian politics, and their instruction through active learning best suits this changing spirit.

This new teaching methodology is capable of empowering both teachers and students, while the teaching-learning process becomes alive and enjoyable with numerous activities encouraging students to think, act and reflect. In this new teaching environment students may perform a game allowing them to experience the life of a minority with its interests and concerns, or attempting to find a solution to a conflict that often emerges due to clashing perceptions. This may create an understanding of diversity and empathy for the needs of others. Like the new methodological direction in teaching other non-religious subjects described above, the new mode of teaching PKn is also a project in the making. Numerous schools and teachers are following this orientation while many others are in the process of adopting it. The most important aspect of this development is that the spirit of teachers for creating a better school environment, and for making the classroom as attractive and instructive as possible for their pupils, is being highly energised.

In contrast to non-religious subjects, the teaching of pelajaran agama in both the madrasah and sekolah has witnessed very little change since the end of the Suharto era. Although agama teachers are very aware of the importance of active learning, only a handful of them have been introduced to or received training in this creative teaching approach. ${ }^{22}$ While acknowledging the importance of this new methodological orientation, the lack of real change in teaching religion should not be seen as entirely negative for a number of reasons: ${ }^{23}$

1. Normative Indonesian Islam, including the form of Islam being taught in both the madrasah and sekolah, remains more open to providing room for wider intraIslamic diversity and differing religious interpretations that lay a foundation for respect toward other faith communities.

2. The division of the majority of the Indonesian Muslim community into major sub-groups of modernists championed by the Muhammadiyah ${ }^{24}$ and

22. In most cases, these agama teachers are introduced to active learning not in order to equip them with a new teaching method for instructing religious courses, but rather to teach a non-religious course, for in addition to teaching religion some agama teachers also teach other subjects. This reveals a problem of mis-match and lack of qualifications among teachers that still haunts Indonesia.

23. Negative changes have clearly been identified in certain areas of Indonesia since rather than moving toward a better appreciation of diversity, the 'flat-earth' conformist perspective of the neoWahhabi puritanical agenda is being disseminated by certain Indonesian Muslims. Fortunately the antipathy and resistance of many local Ulama and Muslim communities dilutes their impact.

24. Muhammadiyah is the second largest Islamic organisation in Indonesia with about 29 million members. It was founded in 1912 as a reformist socio-religious movement, advocating ijtihād (individual reasoning) to meet the modern challenges of Muslims, as opposed to taqli $d$ or acceptance of traditional interpretations propounded by the 'ulama' that may no longer be adequate in meeting human needs. Since its foundation the organisation has focused on educational and social activities, but in the post-Suharto period many of its leaders established a political party. 
traditionalists championed by the Nahdlatul Ulama ${ }^{25}$ where each possesses a differing view regarding specific Islamic doctrines and practices, makes diversity in legal opinions (khilāf) common in schools and beyond in the communities. For example, their debate on the number of cycles ( $r a k i a, \mathrm{pl}$. rak $\bar{a} t)$ in the șalāt al-tarāwīh (recommended night prayers performed in the fasting month of Ramadan) provides Indonesian students familiarity with and appreciation of divergent ritual practice. In observing this type of debate, young children are informed that both viewpoints are soundly Islamic.

3. Traditional Sufi influence on Indonesian Islam also facilitates presenting Islam in a pluralist manner accepting of diversity, especially when students learn how Islam was taught by great Sufi saints in the past accommodating and transforming many local traditions into their da wah (inviting to Islam) techniques including adapting shadow puppet theatre (wayang) in Java or folk dances in Aceh. This abiding sense of the naturalness of embracing diverse traditions would have been strengthened had instructors been trained to teach agama subjects by means of active learning. ${ }^{26}$

Teaching pluralism in democratic-era Indonesia has found an additional venue. With support from a variety of international funding agencies, human rights initiatives have been introduced both at national and local levels. In spite of resistance from certain individuals and the Indonesian military, ${ }^{27}$ human rights education is currently

Muhammadiyah's famous son Dr M. Amien Rais became Speaker of the 1999-2004 Indonesian Consultative Assembly that initiated a great many changes to Indonesian laws. Due to his role in the democratisation of Indonesia that contributed to the fall of Suharto, Rais is known as Bapak Reformasi or 'Father of Reformation'.

25. Nahdlatul Ulama (NU) is the largest Islamic organisation in Indonesia, indeed in the world, with a claimed membership of 35 million. It was founded in 1926 as a response to the modernist agenda, emphasising the need for respect of Islamic intellectual and cultural heritage, including the classical views of different legal madhähib. NU is known for its respect of pluralism and concentrates its efforts on education, health and community development, turning villages in rural Java into more coherent communities in order to help combat poverty. Like the Muhammadiyah, in postSuharto Indonesia NU established a political party and was able to elect its well-known leader Abdurrahman Wahid (grandson of NU's founder Hasyim Asy'ari) as President of Indonesia in 1999. At the time of Wahid's election to the presidency, relations between NU and Muhammadiyah were at their best ever.

26. The lack of training for religion teachers appears to be dictated by the fact that with its limited resources Indonesia has to prioritise its spending, and training agama teachers falls at the bottom of the list. Also, financial assistance to train religious teachers has normally come from Western and international donors who by their very mandate cannot publicly assist "Islam" unless such assistance is packaged in non-Islamic terms.

27. Many Indonesians who resist human rights initiatives perceive them as part of a Western agenda to undermine traditional values and weaken the national government, since human rights are often bundled along with liberal democracy and the global free market economy. One motive for this attitude is the distrust planted by long years of colonial exploitation. The Indonesian military has also resisted calls for a human rights programme from anxiety that it may be used to uncover their complicity in severe abuses against civilians. 
penetrating into the Indonesian school system. Initially this was piloted as a separate subject until it eventually settled upon, and is being integrated into, civic education. The incorporation of human rights into school courses adds a new perspective to the way students may understand religious pluralism. In the past pluralism was taught to Muslim children through the prism of Islamic universalism, yet now they are being exposed to a form of 'religious-less pluralism' ${ }^{28}$ or 'secular pluralism' ${ }^{29}$ The word secular continues to be viewed negatively in the Indonesian context, being understood more as religious-less or anti-religious, rather than as a separation between religion and the public sphere. The fact that some human rights advocates outside of the school system are truly secular in the first sense of secularism, gives many teachers an uneasy feeling about teaching a human rights view of religion.

What has alarmed many Muslims is that a number of prominent human rights propagators openly avow that "all religions are the same and share equal truth", a view advocating ethical relativism denying any binding universal values at the heart of absolutist religious conviction. Therefore, teachers often ignore 'secular' religious pluralism promoted by advocates of human rights, but teach all other principles seen as conducive to Muslim understanding. This implies that human rights are being both used and refused by teachers. Many principles that strengthen conventional wisdom such as rights to life, education, assembly, freedom of speech, cultural and social plurality have been implanted in students, while norms related to secular religious pluralism are often put aside. In spite of careful demarcation of those principles by teachers, students usually get exposed to these ideas either by reading human rights texts or from the media. Whatever their source of information, post-Suharto Indonesia affords many opportunities for students to access different views of pluralism. This advancement has enriched students' understanding of pluralism even while a large majority of them still uphold an Islamic version of religious diversity.

\section{The Experience of Aceh}

What was surveyed above represents national agendas on teaching pluralism in the madrasah and sekolah systems. Now we turn our attention to the experience of

28. A leading ulama of Aceh, Muhammad Natsir Waly, regards certain human rights principles such as freedom of conscience and freedom to believe or not believe in a religion as 'religious-less pluralism' (pluralisme tanpa nilai agama). He is not alone in his opinion, since many Muslim religious leaders in different societies worldwide share his view perceiving human rights as introducing secularist liberal freedom (kebebasan tanpa batas).

29. Human rights norms are often viewed as secular values and thus resistance has also been expressed on this ground. For the reasons of Muslim resistance toward human rights, see Ulama Curriculum Team, Peace Education Curriculum: The Perspective of the Ulama of Aceh (Banda Aceh: PPDMPU, 2004; in Indonesian), 77. 
Aceh in promoting an Islamic view of religious diversity from the absolutist Islamic perspective within both the public high schools of madrasah and sekolah and the private Islamic boarding schools known as dayahs (from Arab. zāwiyah, meaning 'study lodge' or 'circle'). Aceh is Indonesia's westernmost province classed as a 'Special Territory' and maintains a distinctive status within Indonesian geopolitics having experienced bloodshed over most of its historical unity with the Indonesian state. Known for its keen sense of history and identity and fierce resistance to domination by outsiders especially the Dutch colonials, Aceh traces its significant history to the introduction of Islam by the twelfth century onward and to the era when its leaders led a powerful Sultanate in Southeast Asia after the fifteenth century. During that era Aceh's 'ulamā', poets, and scholars made major contributions to the development of the Indonesian-Malay language and to Islamic religious scholarship that culturally unified the entire region.

The denial of Aceh's distinctive history after its joining the Indonesian modern state, coupled with political and economic injustice Aceh experienced afterwards, incited the Acehnese to protest against the central government in Jakarta. One aspect of this resistance was a long lasting insurgency led by the Free Aceh Movement $(\mathrm{GAM})^{30}$ that only came to an end after the signing of a peace agreement between the Government of Indonesia and GAM on 16 August 2005 - in the aftermath of the catastrophe of the December 2004 Tsunami that swept away over 160,000 Acehnese (largely women and children). Ironically, as Indonesia opened up and democratised, Aceh suffered even more. In the past ten years after the fall of Suharto's regime when numerous atrocities and human rights abuses against Acehnese civilians began to surface in 1998-99, the Acehnese and the rest of Indonesia became aware of the scale of Indonesian military abuses in Aceh. ${ }^{31}$ Yet this was not the end of Acehnese suffering for the revelation of these crimes only intensified Aceh's calls for independence by employing various non-violent means available in democratic-era Indonesia. In response to this peaceful political activity by Acehnese students and civil community, Jakarta sent thousands of troops and military personnel to subjugate the Territory, also killing thousands of civilians in their pursuit of GAM fighters. As the conflict intensified Aceh was placed first under martial law and then civil emergency status for over three years, which was only lifted in early 2005 after the Tsunami had devastated the area, to allow foreign humanitarian workers to deliver aid to survivors. In the last couple of years of this conflict over one thousand public schools were burnt down, while many teachers were either killed or forced to leave

30. Gerakan Aceh Merdeka (GAM) was founded in 1976 and spearheaded Acehnese resistance against central government control imposed from Jakarta.

31. See e.g. Aceh: The Untold Story. An Introduction to the Human Rights Crisis in Aceh, ed. Richard Barber (Bangkok: Asian Forum for Human Rights and Development, and Support Committee for Human Rights in Aceh, 2000). 
the conflict zones for their own safety and that of their families. Thus in the first eight years of Indonesia's democratic era Aceh experienced a dark socio-political reality in its relations with Jakarta.

This context demonstrates the challenges encountered by the local governments, local NGOs and international donors who sought to help Aceh. It was in the midst of this traumatic security situation that the local nongovernmental organisation Program Pendidikan Damai (PPD, Peace Education Programme) ${ }^{32}$ was founded in October 2000 with its initial vision to teach an Islamic perspective on peace to both high school and dayah students, in order to prevent them from taking up guns and to impart nonviolent ways of managing conflicts. ${ }^{33}$ Its initiatives were fully supported by the local government and the Muslim religious leaders ( $u l a m \bar{a}$ ') in Aceh, with its first teaching manual Peace Education Curriculum piloted in 25 schools across the province in mid 2001 . The results of this pilot project were highly praised by principals, teachers, and students. UNICEF's external evaluator who specialises in conflict resolution and peace studies evaluated this initiative a year later confirming the earlier finding that "peace education has worked" in transforming the views and attitudes of students. Over the following years the programme has been enlarged to 247 schools targeting more than 75,000 students province-wide; and its teaching manual has been transformed into the Aqidah-Akhlaq Curriculum in the Context of Peace Education, published in 2006, to accommodate more Islamic principles and strengthen the Islamic faith ( $a q \bar{\imath} d a h)$ and ethics ( $a k h l \bar{a} q)$ course taught to high school students. Despite the difficulty due to bloodshed and conflict, this Aceh programme has to be understood within the context of the democratisation of Indonesia which permits local NGOs to flourish and international donors to assist local initiatives including PPD.

In the context of teaching pluralism, the conventional approaches of both pelajaran agama and non-religious subjects reviewed above have also been implemented in Aceh, but with great difficulty due to violent conflict. Civic education and teaching Pancasila values, despite some changes through incorporation of democratic aspirations, did not function in Aceh because it was viewed as a form of subjugation

32. Program Pendidikan Damai was established by Dr Asna Husin in 2000 as a branch of the Washington DC based NGO Nonviolence International (chairman: Dr Mubarak Awad). PPD was registered as a local independent organisation in 2003. This initiative has today reached hundreds of thousands of youth with programmes on peace education, curriculum development, conflict management, pluralism and diversity, human rights-responsibilities and gender partnership. One of the very few civic organisations to survive and operate continuously during the terror of civil chaos under martial law regime, PPD instituted a Peace Education Curriculum in public high schools which was then expanded to dayah students in close collaboration with the provincial Government and the principal 'ulamā' organisations in Aceh.

33. Financial support for this programme was initially provided by UNICEF (sourced from AusAID), but later from CIDA, United States Institute of Peace (USIP), the British Embassy in Jakarta, and the Embassy of Japan. 
toward Jakarta. Therefore a number of civic education teachers began teaching PPD's peace education manual instead of the national PKn books sent by Jakarta. What materials are found in the peace education manual that promote co-existence and common living? Before exploring this issue, we should first present certain characteristics of this book and its sister manual, Peace Education Curriculum: The Perspective of the Ulama of Aceh ${ }^{34}$ which makes both unique.

These pioneering manuals introduce active learning to Aceh, actually being among the first advocates of active, joyful and effective learning (AJEL) in the whole of Indonesia. The teaching techniques comprise games, role-playing, small-group discussion, competition, analysis, data collection and many other procedures placing students at the centre of learning activities. Independent study combined with team work and problem solving is part of the manuals' methodological strengths. ${ }^{35}$ The manuals are also the first teaching materials ever to incorporate Acehnese proverbs and local wisdom tales dealing with pluralism and co-existence utilised as teaching materials and techniques. The integration of Aceh's traditional conflict management mechanisms that are still alive throughout the province is another aspect of peace education appreciation of local heritage.

Furthermore, a close study of universal values and human rights documents coupled with critical analysis of certain global conflicts gives our manuals an international flavour. The incorporation of many stories and case studies occurring in everyday life, and discussion of contemporary local and global issues including corruption, poverty, and current conflicts along with ways to deal with them peacefully, bring these manuals close to home. The integration of informative and animated graphics is a further strength of the books. The most outstanding characteristic of these peace education manuals is probably their Islamic foundation, which forms the rūh (spirit) of the project as a whole. They explicitly state that "Islam is a religion of peace" and therefore the materials and the flow of their arrangement support this spirit, drawn from Islamic resources, classical works, and contemporary studies of both Muslim and non-Muslim origin. This may permit us to argue that the manuals can be seen within the context of both a local initiative and a global agenda, while its active learning methodology makes it attractive to both teachers and students.

Peace education by its very nature deals with many subjects important for creating peace, ranging from advancing democracy to managing conflict, honouring rights to fulfilling responsibilities, providing social pressure to engaging in social control, promoting good governance to preserving nature, the call to respect diversity to encouragement to honour gender equity, and in particular the uplifting of thought

34. This curriculum, known also as the Ulama manual, consists of 382 pages with 11 chapters and 53 modules dealing with a wide range of issues.

35. Those techniques can be summarised in the three teaching approaches emphasised by the manuals: learning by doing, playing for learning and thinking for renewal. 
(jihād al- 'aql, lit. empowering the mind) for reclaiming Islam's primary principle of peace. These and other related topics fall within the manuals' broader understanding of peace. This demonstrates that peace education deals with plurality from many different angles: class disparity, differing access to education and livelihood, diversity in economic opportunities, inequality between men and women, and certainly plurality of culture, ethnicity and religion. Pluralism is therefore addressed in almost every module in the two manuals at times explicitly and other times implicitly, since peace cannot be attained without respect for differences and appreciation of our shared common living. The manuals present plurality as a reality of life that needs to be comprehended for one's own and others' wellbeing. Some of these disparities need to be eliminated or at least reduced to a minimum, such as corruption and economic disparity, while many others including ethnic and religious differences require proper understanding, guidance and wise management. Disparities create many forms of conflict that with appropriate management can lead to compromise and cooperation, but may also cause serious disruptions or even lead to violence when problems are ignored or denied. ${ }^{36}$

The description of the following teaching module, taken from the Aqidah-Akhlaq Manual $^{37}$ taught to high school students, may show how peace education teaches pluralism to Aceh's youth. ${ }^{38}$ One module is titled "We Live in Plurality" and discusses physical, cultural and spiritual plurality as sunnat Alläh (divine natural order) that needs to be accepted by Muslims as a matter of religious principle. ${ }^{39}$ While acknowledging that plurality and human diversity leads to individual and communal pride, it should not lead one to undermine others different from oneself. Instead, such differences have to be seen as elements enriching the life of the human family. The complexity of humans can also produce conflict and social tensions since every individual or community has differing needs and interests. Nevertheless, conflict need not end in violence, but rather can make human existence more dynamic

36. Professor Osman Bakar describes such positive and negative possibilities of plurality and diversity in his monograph The Qur'an on Interfaith and Inter-Civilization Dialogue: Interpreting a Divine Message for Twenty-first Century Humanity (Kuala Lumpur: International Institute of Islamic Thought Malaysia and Institute for Study of the Ummah and Global Understanding, 2006), 17.

37. This manual is now being implemented in 247 high schools in both the madrasah and sekolah systems across Aceh under the religion course (pelajaran agama), and is facilitated by over 500 agama teachers who have been trained in PPD's six-day intensive training programme how to use the manual effectively.

38. The Ulama manual devotes an entire chapter to plurality starting with the practice of the Prophet in the Hudaybiyyah Agreement and in the 'Constitution of Madinah', followed by current pluralist concerns involving religious conflict and cooperation, cultural and ethnic diversity, as well as man-woman partnership as the Vicegerent (khaliffah) of God on earth (pp. 103-325). This manual is now being implemented in 40 Islamic boarding schools (dayahs) across Aceh, every year targeting more than 1,500 future 'ulamā' leaders.

39. See Curriculum Team, Aqidah Akhlaq Curriculum in the Context of Peace Education (in Indonesian, Banda Aceh: Program Pendidikan Damai, 3rd ed., 2007), 169-974. 
preventing stagnation or 'rust' ${ }^{40}$ If conflict occurs over such differences, youth are taught to search for a way of resolving it peaceably through understanding and compromise for the sake of a common good. Thus, "ethnic, national and religious violence contradicts the spirit of Islam which perceives plurality and diversity as wisdom [hikmah] to build friendship [ukhuwwah] creating a willingness to learn and understand one another". ${ }^{41}$

This manual also instructs Acehnese youth about different types of plurality through a number of short stories. Regarding religious diversity the module relates an account by Abū 'l-Ḥasan al-Wāhịidī from his Asbāb Nuzūl al-Qur' ān (a classical Arabic text on the 'Occasions of Revelation' of qur'ānic verses) about the respect the Prophet granted to the Christian delegation of Najrān who came from South Arabia to meet with him. ${ }^{42}$ The Prophet honoured the 60 members of this delegation led by its deacon Abū Hārithah b. al-Qāmah to perform their Christian mass in the Prophet's Mosque, saying: "Let them pray [inside the mosque]." ${ }^{43}$ This noble practice of Muhammad is presented as a model for students to emulate in their treatment of non-Muslims. ${ }^{44}$ Physical pluralism is narrated in the fictional form of an Acehnese female student who studies in Egypt and falls in love with a young black professor from Uganda. She is tormented by not being able to share her feelings with her parents back home in Aceh because of his skin colour. As the young professor awaits her answer to his marriage proposal, she finally asks her parents' blessing. To her surprise, upon her informing them "his skin is very black", her father responds with ease, "My child, since when have you become anti-black skin?" Her mother also reminds her that "Islam does not differentiate human beings over their skin colour."

The same module presents cultural pluralism by another fictional tale describing six young dayah students who come from different areas of Indonesia having different cultures and worldviews but are room-mates ${ }^{45}$ Once they sit to discuss their

40. Ibid., 171.

41. Ibid., 169.

42. Ibid. The module "My Prophet: the Chosen Man [Rasulku: manusia pilihan]" (pp. 38-43) teaches the multiplicity of prophets; while "We: Different but the Same [Kita: beda tapi sama]" (pp. 175-180) promotes an Islamic conception of gender parity.

43. Al-Wāhid̄̄, Asbāb Nuzūl al-Qur'ān, cited in ibid., 171.

44. These peace education books were initially created in response to the Aceh conflict, but with the projection that they may be used in other parts of Indonesia and the Islamic world. Thus, even though inter-religious conflict was never an issue in Aceh, religious pluralism forms an important component of the manuals.

45. Though the Aceh conflict was largely between GAM and the Indonesian military-government, it was occasionally transformed into horizontal ethnic conflict between Acehnese and Javanese, or between Acehnese and other ethnic groups such as Gayonese and people of Alas, since the Indonesian military created militias derived from these non-Acehnese ethnic groups to counter GAM at the community level. This caused bloody conflicts between the different ethnic groupings inhabiting Aceh. Consequently, harmonious ethnic communal living and cultural co-existence is an important topic that is not ignored in these two manuals. 
different ways of life and cultures in their respective homelands. At the beginning their discussion is constructive; but as they try to win over each other, they begin to tease and insult one another and almost get into a fight. Their loud voices make their teacher aware of what is going on, who then comes to help resolve their conflict until they all realise what they are doing and forgive one another. These and similar stories are read and internalised with the aid of activities using games, role-play, discussions or cause-effect analyses in order to provide students with a deeper understanding of the importance of respect for differences and equipping them with skills on how to resolve conflict when it occurs. To further their comprehension, the above activities are assisted by teaching instruments such as charts, analytical questions, puzzles and other inexpensive materials found in the students' environment including fruits and flowers.

This mode of teaching has numerous advantages:

1. It overcomes the old method of teaching religion in the form of indoctrination, while maintaining the sacred enduring values of Islam as relevant guidance to humanity. The conventional methodology of ceramah is utilised only in combination with many other creative techniques thus making the teachinglearning process both instructive and enjoyable. Consequently the religion class - i.e. ' $a q \bar{l} d a h$ (creed) and $a k h l \bar{a} q$ (Islamic ethics) - is no longer a dry boring course.

2. This learning methodology requires the creativity of both teachers and students creating a class environment wherein students learn not only from their teachers but also among themselves. Students are encouraged to work as a team while recognising an innate hierarchy in their intellectual and practical abilities.

3. The manual and its teaching approach generates critical thinking among students, for even the idea of the absolute truth of Islam is imparted in a fashion that provides a great deal of nuance and reflection. Rather than teaching Islam in a black and white manner, the manual presents the all-inclusive superiority of Islam reaching the highest plane of absolute truth, spawning an Islamic sense of security among students that, to recall the view of the Archbishop of Canterbury, plays an important role in securing social unity and cohesion.

4. On the issue of spiritual and religious pluralism, the manual rises above the exclusivist approach of "for you your religion and for me mine" by imparting the issue of the more encompassing nature of Islam that perceives religious pluralism as a divine intent (irādah) in order to establish benevolence and goodness (alkhayrāt) in this world. ${ }^{46}$ The manual's inclusive approach can strengthen the

46. This inclusive presentation has to be delivered in such a way in order to maintain the delicate balance as not to generate suspicions from the literalist groups that may openly criticise the manual in order to create doubts of the book among students, teachers and the ulama. So far, both the Ulama and High School manuals have been able to overcome this challenge. 
students' sense of 'islamicity' and respect of the Other, for it moves from the narrow literalist Islamic worldview toward the 'Other' to the more elevated wise character of Islam as intended by the Qur'an. Such a mode of teaching has given rise to the rare phenomenon of making Islamic teaching accessible even to non-Muslim students, as attested by one high school in Suro, Southeast Aceh. ${ }^{47}$ Some Acehnese Christian students study the manual out of a genuine appreciation for its generous high-minded Islamic worldview. ${ }^{48}$ Is there any better positive perception of Islam than the sincere view of these young Christian minds in Suro, Aceh?

Another major distinction of the Aceh peace education initiative from that of the national programmes in cultivating a wise appreciation of pluralism is that PPD's peace education from the start concentrated on empowering the teachers of religion (guru agama). The teachers who have been trained to implement the two manuals learned not only new knowledge and conflict management skills, but also active, joyful and effective learning (AJEL). Why must agama teachers be the focus of peace education attention? One obvious reason is that religion teachers have frequently been ignored by other training programmes, and the Aceh initiative seeks to remedy their disadvantages. Thus, the teachers have a keen appreciation for this rare educational opportunity. Secondly, in spite of the widespread perceived importance of religion, the common unimaginative mode of teaching it has never been improved and therefore the required religion course became a boring tiresome subject for many young students. With new methods infusing the teaching-learning process these agama teachers have transformed pelajaran agama into an attractive stimulating educative course, making it highly anticipated by both students and teachers and placing pelajaran agama in its currently honoured position. Thirdly, teaching the Islamic view of pluralism and peaceable conduct can best be performed by guru agamas, for they have a deeper understanding of the issues due to their familiarity with qur'ānic principles and Prophetic traditions, as well as with the

47. This is one of a few schools in Aceh where Muslim and Christian students each comprise 50 per cent of the student body. As indicated above, Christian students must learn religion in the school from a Christian teacher, just as Muslim students learn from a Muslim teacher. However, with this new approach to teaching Islam, even Christian students are happy to join the Islamic religious course as reported by the peace education-agama teacher (PPD staff's interview with this teacher of 21 July 2008).

48. Several Christian students interviewed by phone for this study indicated that they like to join the Islamic agama-peace education class not only because its "teaching techniques are very attractive and we have a lot of fun learning it", but also because "the manual presents non-Islamic religions in a dignified way [secara mulia]". They study Islam at their own request and with the permission of their Christian teacher in order to benefit from this generous Islamic worldview [pandangan Islam yang menyejukkan]. (Interview with five Christian students in Suro, conducted by phone, 13 December 2008.) 
contemporary socio-cultural complexity of human life in their environment. Finally, teachers of religion are very often informal leaders in their respective communities; teaching them new knowledge and skills is like catching two birds at once, for the new understanding and capacities they have acquired in their training will be taught not only to their students at schools but also to adult peers in their communities.

\section{Concluding Remarks and Recommendations}

Our brief analysis of educating for an Islamic view of pluralism through pelajaran agama and non-religious courses in the madrasah and sekolah schools throughout Indonesia, as well as through ${ }^{\prime} a q \bar{l} d a h / a k h l a \bar{q}$-peace education in the specific context of Aceh, highlights a viable new synthesis in teaching religion as a whole within a Muslim society. Above all a religion course should provide room for students to think, act and reflect over the sacred and enduring values of Islam as guidance promising to bring benevolent loving-kindness ( $\mathrm{rahmah}$ ) to humanity. Furthermore, teaching plurality must manifest the proper qur'ānic worldview which proclaims that differences among the human family should be understood as an inherent divine directive in creation serving a higher purpose. This understanding facilitates partnership and cooperation between differing individuals and groups within the larger community - rather than self-interest driven conflict and divisive exclusivity - thereby giving expression to the underlying spirit of the qur'ānic pluralist vision. Such harmonious partnership within the human family is a translation of the highest spiritual objective of attaining constant divine consciousness $(\operatorname{taq} w \bar{a})$. In addition, educating for pluralism must reflect high-minded Islamic generosity with its dignified view of other faiths - as attested by the Christian students in Suro, Aceh - for this quality is indeed a manifestation of Islam's superiority and security in possessing an absolute truth. Finally, teaching Islam should be accomplished in as attractive a manner as possible to young Muslim minds and hearts in our global age, without compromising religion's sacred nature and its special position in human consciousness, aspirations and activities. 